\title{
Die oue weier om te verdwyn
}

\author{
J H le Roux \\ (Universiteit van Pretoria)
}

\section{ABSTRACT}

\section{The old refuses to disappear}

This article deals with some aspects of presentday Pentateuchal research. It is stated that although the basic elements of nineteenth century Pentateuch criticism still prevail, the study of the Pentateuch has also changed in many ways. Pentateuchal studies did not, however, escape the hermeneutical insights of the twentieth century. This opened up new ways of understanding and evaluating reseach results. More emphasis is also being laid on the final text and the forces which shaped the final form of the Pentateuch. One important paradigm shift is the rejection of the Davidic-Solomonic era as the earliest context of the Pentateuch in favour of the neo-Assyrian time. During this period the Pentateuch originated, and was meant as resistence against the neoAssyrian powers.

\section{INLEIDING}

Hierdie artikel handel oor die Pentateugkritiek wat sy twee-eeue lange gang onverstoord voortsit en nog steeds (al is dit in ander gestaltes) by ons is. Dit word aan ons vriend en kollega, Wil Vosloo, opgedra. Ons paaie het lank gelede reeds gekruis. Eers was ons saam studente en toe jare saam kollegas by Unisa en die Universiteit van Pretoria. ' $n$ Lesing van hom oor die Pentateug, amper dertig jaar gelede, bly my nou nog by. Dit was voor enkele Unisakollegas en hy het oor die Pentateugkritiek gepraat. 'n Onderwerp waaroor ons destyds nie graag gepraat het nie. Daarvoor was die nagevolge van die Du Plessisstryd nog te sterk. Met groot kundigheid het Vosloo egter die veskillende moontlike teorieë verduidelik en toe sy eie siening begin formuleer. Later sou hy dit nog in groter besonderhede uitwerk (vgl Vosloo 1978:1-100; 1988:158-174). In sy verstaan van die Pentateugkritiek (asook die hele Ou-Testamentiese wetenskap) het Vosloo nooit gehuiwer om die skerpkante van die ondersoek deeglik onder loep te neem nie. Hy was en is nog steeds 'n gerypte Ou Testamentikus wat die wetenskap baie ernstig neem, maar alle probleme op sy tipiese deeglike, skerpsinnige en helderdenkende manier hanteer.

Gedagtig aan daardie lesing, sy jarelange Pentateugonderrig en ons besondere vriendskap word onderstaande met groot dankbaarheid aan Wil Vosloo opgedra. Dit vertel van 'n bepaalde aanpak tot die Pentateug 
wat sy greep steeds behou en enkele nuwere insigte in verband met die Pentateug.

\section{WAAROM DIE VOLHARDENDE VOORTBESTAAN VAN DIE PENTATEUGONDERSOEK?}

Gedurende die afgelope twee eeue het die kritiese Pentateugondersoek geweldig onder skoot gekom. Verskillende pogings is aangewend om dit te ondermyn en te diskrediteer. Op 'n interessante manier het dit egter die kritiek oorleef. Uiteraard het baie dinge verander. Die Pentateugkritiek het ' $n$ ver ent sedert die Graf-Kuenen-Wellhausen-hipotese gevorder (vgl Houtman 1994:98-121; Otto 1995:163-191; 1996:332-341). Daar is 'n 'groei' in navorsingsinsigte; daar is 'n groter oortuiging dat die Pentateug se ontstaan en groei nooit volledig begryp en beskryf kan word nie; daar is 'n groter bewustheid van die teoretiese aard van die ondersoek; daar het groot variasie op die sogenaamde "vierbronneteorie" gekom; daar is ander kontekste en daterings vir die ontstaansproses voorgestel; daar is 'n groter gevoeligheid vir die finale of die kanoniese gestalte van die Pentateug; daar is 'n duideliker wete dat die Pentateug se ontstaan en verstaan in samehang met die wording van Genesis $1: 1-2$ Konings 25:30 verstaan moet word; daar is die aanvaarding dat raaiwerk 'n onvermydelike deel van die Pentateugondersoek is (vgl Rogerson 1984:9-100; Blum 1984:478-506; Zenger 1998:66-176; Otto 1999:1-14; Schmid 1999:358-379; Van Seters 1999:30-57).

Ten spyte van al die kritiek teen en selfs verwerping van die soort Pentateugondersoek wat by Simon, Astruc, Eichhorn en De Wette begin is, deur Wellhausen, Gunkel, Alt, Noth en Von Rad verder gevoer is en by navorsers soos Van Seters en Eckart Otto nuwe hoogtes bereik het, het die Pentateugkritiek nog nooit opgehou om te bestaan nie (vgl Hayes \& Prussner 1985:100-137). Selfs vandag nog is dit die glansstuk van die Ou-Testamentiese wetenskap. Wat oor die Pentateug gedink, gesê en geskryf word, is beslissend vir die verstaan van die res van die Ou Testament. Verskillende redes kan hiervoor aangevoer word:

- Die historiese verstaan van tekste het nog nooit sy bekoring verloor nie. Kennis van die ontstaan van 'n teks/die Pentateug bly belangrik vir die teologiese verstaan daarvan. Geskiedenis en teologie sluit mekaar nie uit nie (vgl Von $\operatorname{Rad} 1957: 111-134$; Albertz 1992:17-43). Alle nadenke en spreke oor God is histories bepaald. Elke poging om die Pentateug in sy historiese gang te verstaan, is dus ook ' $n$ poging om iets van Israel se verstaan van God te begryp. Israel het nooit op 'n gegewe oomblik finaal en absoluut oor God gepraat nie. In elke era is weer en weer probeer om iets van God te begryp en dit onder woorde te bring. In elke situasie is telkens opnuut getrag om anders en nuut oor Hom te 
praat en in die Pentateug word die neerslag van hierdie verskillende pogings gevind. Elke kritiese ondersoek van die Pentateug moet dus iets van hierdie lewendige proses van geloofsinterpretasie weerspieël (Pannenberg 1970:1-38; 1973:1-46; De Knijff 1980:135-145; Sandys-Wunsch \& Eldredge 1980:133-158; Mehlhausen 1984:643-658; Merk 1984:1-3; Saebo 1987:1-16; Gabler 1992:489-502; Graf Reventlow 1995:132-148; Collingwood 1994:213-214,441-442; Le Roux 1997:410-423).

- Die Pentateugondersoek het in baie opsigte iets van die Kuhniaanse "normale wetenskap" bereik: daar is 'n duidelike "historiese" groep geleerdes wat vanaf die begin van die negentiende eeu tot vandag toe die Pentateug op 'n spesifieke manier benader; hulle het besluit hoe die Pentateug wetenskaplik ondersoek moet word; hulle het sekere wetenskaplike waardes (soos die belang van die wordingsgeskiedenis, navorsingsgeskiedenis, metodes, ens) gekoester; hulle het die aard van wetenskaplike waarheid bepaal; hulle het van individuele navorsers 'n sekere soort wetenskaplike "commitment" gevra; hulle het hulle gedagtes in tydskrifte, boeke en kongreslesings verder uitgewerk. Kortom: hulle het 'n sekere soort benadering tot die Pentateug "genormaliseer", dit voortdurend verfyn en toe as standaard vir wetenskaplike navorsing gestel (Kuhn 1970:23-34; Van Huyssteen 1986:63-87).

- Die dominante paradigma (tot die verstaan van die Pentateug) bly steeds van krag en sal klaarblyklik nie sommer vervang word nie. So 'n paradigma rig die manier waarop die werklikheid (lees: Pentateug) benader moet word; dit omvat die oortuigings, waardes en tegnieke wat in ' $n$ bepaalde groep Pentateugondersoeker leef; dit verskaf die apparaat (teorieë, konsepte en metodes) om hierdie werklikheid (lees: Pentateug) te bestudeer. Enkele paradigmakenmerke van die kritiese Pentateugondersoek is die volgende: die Pentateugtekste het in verskillende leefwêrelde gestalte gekry; die finale Pentateugteks verteenwoordig maar net een moment in 'n groot beweging; tekswording en teksverstaan is onafskeidelik; die heersende Pentateugteorieë is steeds kragtige verklaringsmeganismes; sulke teorieë verleen 'n uiters beperkte maar tog belangrike toegang tot die ontstaan van 'n teks; sekere tye in die geskiedenis van Israel (Dawid en Salomo, Hiskia en Josia, die ballingskap en na-ballingskap) bly die beste onstaanskontekste vir die Pentateugondersoek; kennis van Israel se godsdiensgeskiedenis verleen die verstaanshorison waarteen die Pentateug verstaan moet word (vgl Wellhausen 1963:1-6; Von Rad 1957:13-109; Noth 1972:1-7; 
Rendtorff 1983:1-79; Gottwald 1985:135-147; Albertz 1992:1743).

- Die histories-kritiese metode bly steeds 'n doeltreffende benadering om die historiese gang van die Pentateug te ondersoek (Mcbride 1981:530-543; Seebass 1982:520-524; 1987:441-451; 1996:185-209; Schmidt 1991:211-222; Kratz 1997:367-378; Zenger 1997:435-446). Gedurende die twintigste eeu is groot druk egter op hierdie manier van teksverstaan geplaas. Van die swakhede en beperkthede hiervan is die wetenskaplike gemeenskap bewus (Gottwald 1985:5-34). Aan die ander kant is die beperkthede van elke wetenskaplike metode (en nie net die historiese kritiek nie) ook al hoe meer besef: dit is sosiaal-histories bepaald, dit is bloot ' $n$ spel van moontlikhede, dit is maar net een manier waarop die werklikheid benader kan word, dit kan nie die betekenis van die werklikheid (lees: teks) verskaf nie en geen (teks)waarheid ontbloot nie (Gadamer 1990:9-15,108-129,133-139,276290). Kortom: ' $n$ metode is niks anders as ' $n$ bepaalde benadering tot die werklikheid wat op 'n sekere manier sekere raaisels in die wetenskap wil help oplos nie. Die historiese kritiek se waarde bestaan daarin dat dit help om sekere historiese raaisels in verband met die Pentateug op te los. Niks meer nie! Dit het egter oor die eeue 'n kragtige metode gebly.

\section{DIE PENTATEUG IN SY FINALE GESTALTE}

Die twintigste eeuse klem op 'n teks se finale gestalte het ook die Pentateugkritiek beïnvloed. Tans word die waarde van die finale teks vir die Pentateugondersoek al hoe meer beklemtoon. Dit moet as vertrekpunt dien. Daar moet elke studie van die Pentateug begin. Binne 'n histories-kritiese denkraamwerk is die blote fokus op ' $n$ "kanoniese" of "immanente" studie van die Pentateug egter nie voldoende nie. Iets moet bygevoeg word: kennis van die tyd en omstandighede waarin die Pentateug gekanoniseer is. Vir Von Rad was dit al belangrik om by die reusige eindgestalte van die Heksateug te begin en vandaar sistematies na die kleinste eenheid, "Das kleine geschichtliche Credo", af te boor (Von Rad 1971:9-86). En eers as hierdie kleinste eenheid beskryf is, kon die bouproses vanaf die credo tot die eindgestalte onderneem word.

'n Belangrike hedendaagse trend in die Pentateugnavorsing is die vraag na die sosiale en politieke kragte wat tot die ontstaan van die finale teksgestalte aanleiding gegee het. Wat het gebeur dat die Pentateug sy eindgestalte bereik het? Een moontlike antwoord word in die bewind van die Perse gesoek (Albertz 1992:497-504). Anders as die Assiriërs en die Babiloniërs het die Perse baie meer gedesentraliseer. 
Klem is eerder op die streeksvlak en plaaslike inisiatiewe geplaas. Klaarblyklik het die Perse hulle reuseryk as 'n organisme, wat uit verskillende lande, volke en gebruike bestaan het, beskou. Interessant is dat die Persiese rykswette nie uit een enkele gekodifiseerde wet bestaan het nie. Daar is vir 'n verskeidenheid voorsiening gemaak. "De facto" het die Persiese wette uit nasionale sowel as 'n veeltal van streekswette bestaan. Elkeen van hierdie onderdanige volke, so ook die mense van Jehud, het hulle lojaliteit teenoor die Perse uitgeleef, deur hulle eie religieuse wette na te kom en hulle eie instellings te besoek. Deur die eie wette en gewoontes te eerbieding, is die Persiese owerheid gedien en geëer (Koch 1984:49-109).

In hierdie Persiese leefkonteks het die Pentateug sy finale gestalte gekry. Anders gestel: die Tora (Pentateug) was die gevolg van die verligte Persiese denke en optrede (Frei 1984:9-43). Volgens Esra 7:1-10 het Esra in die sewende regeringsjaar van die Persiese koning, Artasasta, met ' $n$ aantal Israeliete, priesters, Leviete, tempelsangers, poortwagte en tempelslawe na Jerusalem teruggekeer. Esra het met 'n spesifieke opdrag in Jerusalem aangekom:

Hier volg 'n afskrif van die volmag wat koning Artasasta verleen het aan die geleerde priester Esra, wat op hoogte was van alles in verband met die gebod van die Here en met sy voorskrifte aan Israel: "Artasasta, koning oor ander konings, aan die priester Esra, die skrifgeleerde in die wet van die God van die hemel ... Ek gee hiermee opdrag dat enigiemand in my ryk wat tot die volk Israel, sy priesters of sy Leviete behoort en wat wil gaan, met jou saam na Jerusalem toe kan gaan. Jy word deur die koning en sy sewe adviseurs afgevaardig om aan die hand van die wet van jou God waarin jy onderleg is, vas te stel hoe sake in Juda en Jerusalem staan ... Wat die God van die hemel ook al vir sy tempel vereis, moet met toewyding gedoen word, sodat sy toorn nie oor die ryk van die koning en sy seuns kom nie ... Neem ook kennis dat julle nie gemagtig is om belasting, heffing of tol te eis van enige priester, Leviet, tempelsanger, poortwag, tempelslaaf of enigeen wat in die tempel van hierdie God werk nie ... Jy, Esra, moet volgens die wysheid waaroor jy beskik soos dit jou deur jou God gegee word, regeerders en regters aanstel wat die regspraak kan behartig vir al die mense in Wes-Eufraat, vir almal wat die wet van jou God ken. Vir dié wat dit nie ken nie, moet julle dit leer. Enigeen wat hom nie hou aan die wet van jou God en die wet van die koning nie, moet streng gestraf word, met die dood of met verbanning of met ' $n$ boete of met gevangenisstraf (Esra 7:11-14, 23-26). 
Die wet wat Esra moes afkondig, was Joods ("die wet van jou God") wat ook deur die koning as Persiese rykswet aanvaar is ("en die wet van die koning"); die navolging van hierdie wet deur "al die mense in WesEufraat" het ook in die belang van die hele Persiese ryk geskied; die getroue nakoming van die wette was 'n uitdrukking van lojaliteit aan die Persiese ryk; oortreding van die Joodse wette was tegelyk ook 'n skending van die Persiese reg; straf het gewag op diegene wat hulle nie aan die wet van jou God en die wet van die koning gehou nie. Die tora of die Pentateug was dus 'n gawe van die Perse en dit het waarskynlik in die jaar $398 \mathrm{vC}$ finale beslag gekry (Zenger 1998:79-82). Vir die verstaan van die Pentateug is kennis van sy kanoniseringsproses belangrik (vgl volgende paragraaf).

\section{DIE PENTATEUG AS KOMPROMISBOEK}

In sy finale vorm weerspieël die Pentateug iets van die botsende teologies kragte wat dit gevorm en geslyp het. Soos wat die Pentateug in sy finale gestalte voor ons lê, klink die naklanke van die groot verskille in die na-ballingskapse nadenke oor God. Dalk baie meer as in die verlede word die Pentateug tans bewustelik as 'n "kompromisboek" gelees en verstaan: dit bestaan uit 'n ryke verskeidenheid van materiaal met verskillende teologiese gesigspunte wat tot 'n eenheid geslyp en geboetsier is (Albertz 1992:495-535).

Ter illustrasie let ons op twee "hoofbewegings", die nie-priesterlike en priesterlike groepe, se bydraes. Klaarblyklik het albei op die Persiese bevel gereageer en was hulle tegelykertyd in Jerusalem aan die werk. Albei het dit as ' $n$ geleentheid gesien om die Joodse identiteit op so 'n manier literêre gestalte te gee dat dit oraloor deur Jode aanvaar sou word. In albei was 'n teologiese gistingsproses aan die gang wat uiteindelik tot twee verskillende teologiese denkrigtings aanleiding gegee het. Kortom: albei wou 'n verhaal oor Israel skryf (Gottwald 1985:457-482; Stolz 1996:163-187).

'n Kernprobleem was die beginpunt van die verhaal. Hoe moes Israel beskryf en verstaan word? By watter geloofstradisies in Israel se geskiedenis moes die skrywers aanhak? Watter tradisies het Israel op daardie stadium van sy geskiedenis die beste getipeer? Was Israel primêr 'n kultusgemeenskap, 'n staatsgodsdiens of 'n gemeenskap van profete? 'n Ingrypende en beslissende keuse, wat die ganse geskiedenis van Israel sou bepaal, is gemaak toe hierdie groepe op die voorstaatlike godsdiens besluit het (Noth 1972:42-62; Schmid 1999:152-165). Israel se vroeë geskiedenis is as uitgangspunt geneem. Alles sou om die belofte aan Abraham (of die aartsvaders) en die verlossing uit Egipte draai (Schmidt 1983:28-37). Dit is tog belangrik dat Israelse profetiese tradisies en die era van die konings nie die beslissende toets deurstaan het nie. Klaarblyklik was die val van Jerusalem in $586 \mathrm{vC}$ hiervoor verantwoordelik. 
Die ontnugtering in die konings het hierdie twee groepe van ' $n$ nuwe magsera laat afsien; die politieke optrede van die profete het hulle klaarblyklik ook kopsku vir hierdie instelling gemaak. Hierdie boek (Pentateug) wat in die tyd van koning Artasasta van Persië sou ontstaan, moes om die era van Abraham en Moses wentel. In hierdie vroeë verhale moes Israel sy identiteit as geloofsgemeenskap vind (Stolz 1996:187203).

Dit is interessant hoe die nie-priesterlike kringe hierdie verhaal aangepak het. Die verhaal van Abraham (of aartsvaders) het gedurende die ballingskap in belangrikheid toegeneem (Blum 1984:362-389). Beloftes is aan Abraham gemaak, maar dit is telkens uitgestel. Abraham ervaar egter op ' $n$ unieke manier die nabyheid van God en word die persoon wat ten spyte van alles in God bly glo (Preuss 1992:2-18). Deur die Pentateug met Abraham te laat begin, wou die nie-priesterlike teoloë die waarde van 'n persoonlike verhouding met Jahwe beklemtoon (Albertz 1992:47-68). Alles mag nie maar net in die kultus en offers opgaan nie. Die Jahwegodsdiens impliseer ' $n$ persoonlike verhouding met God. Vir die Jode tydens die Persiese diaspora was Abraham 'n model: ' $n$ verhouding met God is moontlik selfs ver weg van Jerusalem. In die uittog (ook die woestyntyd en die Sinaigebeure) is die eintlike aard van God ontdek: Hy is 'n God wat red. Hy het die jammerklagte van Israel in Egipte gehoor en hulle uit die slawediens gelei. Hierdie siening het ook 'n bepaalde leefwyse van broederskap en van omgee vir mekaar geïmpliseer (Dt 5-28) (Otto 1994:175-256).

Binne die priesterlike kringe was dit onmoontlik om Israel los van die tempel, die kultus en die priesters te dink. Tydens die ballingskap het Esegiël sy denke daaroor gevorm en dit is deur profete soos Haggai en Sagaria 1-8 tot vervulling gevoer. In die tempel sou die volk opnuut weer God se teenwoordigheid ervaar. In die Jerusalemse kultus sou die heil van God opnuut ondervind word. Die tempelkultus het die hartslag van Israel se verhouding met die God gevorm. Nooit sou die priesters hierdie teologiese insig kon prysgee nie. Dit het die kern van hulle teologiese denke gevorm. Interessant is die manier waarop die "kompromis" met die nie-priesterlike groepe gemaak is: die vroeë geskiedenis is gebruik om die kultus te begrond. Vir die priesters was die voor-staatlike era ook die "ideale tyd", maar hulle het die vroeë geskiedenis (aartsvaders, uittog, woestyn en Sinai) so vertel dat dit Israel se kultus histories legitimeer. Israel se kultus het dus uit die geskiedenis gegroei (Schmidt 1982:91-108; Preuss 1985:713-718; Rendtorff 1983:99111,166-174; Zenger 1983:27-49; 1997:435-446; 1998:142-176)

As teologiese kompromiswerk het die finale gestalte van die Pentateug ' $n$ meerduidige betekenis. Vir die priesters het die kultus en die wette uit die vroeë geskiedenis gegroei. Israel se bestaan en voortbestaan was dus afhanklik van 'n lewe in noue verbondenheid met die 
tempel en die kultus. Dit was ook die enigste manier waarop die Jode in die Persiese tyd kon oorleef. Vir die ander groep was die persoonlike verhouding met God die belangrikste en Israel kon slegs oorleef in 'n gemeenskap waarin mense vir mekaar omgegee het. Albei strominge het opreg probeer om Israel se identiteit en die aard van die verhouding met God te omskryf. Enige kritiese ondersoek van die Pentateug moet dus met hierdie fynere nuanses rekening hou.

\section{DIE VROEGSTE VERSETSLITERATUUR \\ PENTATEUGDELE}

AS

Dekades lank is die beginpunt van die Pentateug in die bloeityd van die Dawid-Salomo-era gesoek. Israel se nuut ingestelde monargie het die ideale konteks vir die eerste literêre grondslag van die Pentateug gevorm: die nuwe koninkryk moes teologies begrond en histories gelegitimeer word. Belangrik is dat hierdie begronding ' $n$ literêre gestalte aangeneem het. Losstaande kultiese verhale en mondelinge oorlewerings was nie meer voldoende nie. Alles moes op skrif gestel en in ' $n$ samehangende verhaal vertel word. En die eerste "skrywer" van so 'n verhaal was die Jahwis. Hy het beslag aan die Heksateug gegee: "Der Theologe, den wir Jahwist nennen prägte die Gestalt des Hexateuchs mehr als jeder andere" (Von Rad 1971:55). By die samestelling daarvan het hy veral oor twee elemente beskik: die credo wat as basis vir sy werk gedien het en 'n groot hoeveelheid materiaal wat vroeër aan die kultus gekoppel was. In die credo is enkele hoofmomente in Israel se geskiedenis aangetref en die Jahwis het hierdie kanoniese weergawe van die verlede netso aangewend. Baie belangrik vir hierdie denke was dat die Jahwis die jong staat teologies gelegitimeer het. Op verskillende maniere het dit die Dawid- en Salomokoninkryk ondersteun (Von Rad 1971:9-86; Schmidt 1982:76-81; 1984:90-101).

Tans word die begintyd van die Pentateug heel anders verstaan. Dit het onder andere te make met die geweldige druk waaronder die Dawid-Salomo-era tans verkeer. Daar is 'n toenemende neiging om die bestaan van so 'n periode in Israel se geskiedenis of te ontken of te minimaliseer (Davis 1994:28-40; 1995:21-45,57-71; Cahill 1998:34-41; $\mathrm{Na}$ 'am 1998:42-44). Aandag word nou eerder twee eeue later en op die neo-Assiriese ryk gevestig. In die smeltkroes van die neo-Assiriese oorheersing het die Pentateug sy gestalte gekry.

Alles het gedurende die negende eeu gebeur toe Assirië 'n wêreldmag geword het. Sanherib (704-681), die seun en opvolger van Sargon II, het op ' $n$ stadium besluit om al sy aandag op Jerusalem te fokus. Klaarblyklik omdat Hiskia die Assiriese bewind verontagsaam, tribuut geweier en met ander saam teen die Assiriërs gekonkel het. Sanherib se veldtog teen Jerusalem en Hiskia het 'n merkwaardige afloop gehad. Hy het ' $n$ hele klomp Judese dorpe en stede, soos byvoorbeeld Lakis, aange- 
val, geplunder en verwoes. Jerusalem het al die geweld gespaar gebly omdat Hiskia 'n groot tribuut betaal het. Dit was nietemin 'n angswekkende tyd in Jerusalem. Hiskia het self gesê: "Dit is 'n dag van rou. Ons is in die moeilikheid en ons is verneder. Ons is soos vrouens wat in die kraam is, maar nie die krag daarvoor het nie" (2 Kon 19:4). Iets dramaties het toe gebeur. ' $n$ Ethiopiese leër was op pad om die Assiriese aanval af te weer. Een nag het hierdie twee leërs teenoor mekaar kamp opgeslaan. Gedurende die nag en voordat die slag kon plaasvind, het groot verwarring en ontsteltenis in die Assiriese kamp ontstaan en die Assiriërs het in chaos en vernedering gevlug. Wat gebeur het, weet niemand nie. Hierdie gebeure het egter 'n groot indruk op die Jerusalemmers gemaak en hulle het dit as 'n wonder geïnterpreteer: "Daardie nag het 'n engel van die Here gegaan en honderd vyf en tagtig duisend man in die Assiriese kamp doodgemaak. Toe die Assiriërs die môre vroeg opstaan, lê die lyke almal daar. Koning Sanherib van Assirië het toe kamp afgeslaan en hy is terug Nineve toe en het daar gebly" (2 Kon 19:35-36).

In $697 \mathrm{vC}$ het Manasse die bewind by Hiskia oorgeneem, maar hy kon nooit die Assiriese beheer van hom afskud nie. Hy moes trouens as Assiriese vasaal swaar belasting betaal en die skerpkant van die Esarhaddonverdrag voel. As jonger seun van Sanherib het Esarhaddon baie bekommerd oor sy opvolger geword en het baie deeglike planne beraam om sy koningskap te verseker en die land te beskerm. In $672 \mathrm{vC}$ het hy verteenwoordigers van oor sy hele ryk laat kom en hulle laat sweer. Deur middel van hierdie eed moes hulle belowe om sy begeertes in verband met sy eie opvolging te respekteer. Almal (ook Juda) moes die eed gehoorsaam. In die proses is die onderworpe state (so ook Juda) net nog verder verneder en hulle staatsmag net verder afgekraak (Miller \& Hayes 1986: 340-376).

Die ergste van die Assiriese uitbreidingspolitiek was die religieuse gevolge wat dit ingehou het. Volgens Assiriese gewoonte het hulle hulle ryksgod, Assur, op die oorwonne volke afgedwing. Alle eer moes aan Assur gebring word en hierdie god moes aanbid word. So intens was die religieuse druk dan niemand dit kon ontsnap nie. Van Manasse word byvoorbeeld vertel hoe hy by die Assiriërs se godsdienspolitiek moes inval: "Hy het sy eie seun as offer verbrand, hom besig gehou met goëlery, waarsêery en toordery, en meegedoen aan die oproep en raadpleging van geeste. Hy het baie verkeerde dinge gedoen in die oë van die Here en Hom uitgetart. Die Asjerabeeld wat hy laat maak het, het hy opgestel binne-in die tempel, die plek waarvan die Here vir Dawid en sy seun Salomo gesê het: "In hierdie tempel en in Jerusalem wat Ek onder al die Israelitiese stamme uitgekies het, vestig Ek my Naam vir altyd"” (2 Kon 21:6-7); (Albertz 1992:291-304; Preuss 1992:305-316).

In hierdie smeltkroes van politieke magsoorheersing en religieuse sinkretisme moet die begin van die Pentateug gesoek word. Teenoor die 
Assiriese politiek is ' $n$ teenkonsep ontwikkel: Israel bewoon die land wat Jahwe met ' $n$ eed beloof het en daarom moes Hy alleen aanbid word. In sy vroegste gestalte was die Pentateug dus 'n versetskrif teen die Assiriërs: die Jerusalemse geskiedswerk (vgl hieronder) was 'n versetspoging; in Deuteronomium 13:2-6* word die aansprake in die Essarhadonverdrag geheel en al omgekeer en op Israel se verhouding tot Jahwe toegepas; die verbondsteologie in Eksodus en Deuteronomium wou kritiek teen die neo-Assiriese heerskappy uitspreek; die Mosesfiguur was as kritiek teen die neo-Assiriese koningsideologie bedoel. Hierdie versetspoging is op ' $n$ briljante manier uitgevoer: die heersende Assiriese idees en motiewe in verband met staatsmag en godsdiens is oorgeneem en met ' $n$ radikaal nuwe en ander betekenis gevul. Assur, die Assiriese ryksgod was nie die enigste ware god nie, maar Jahwe; die land was nie gawe van Assur nie, maar van Jahwe; die koning was nie Assur se plaasvervanger op aarde nie en hy het ook geen aanbidding nie verdien nie; die volk was lojaliteit aan Jahwe en nie aan die koning verskuldig nie; die volk en nie die koning nie, moes sekere religieuse verpligtinge nakom. Kortom: Assiriese idees en terminologie is oorgeneem en die angel is daaruit geneem. Alles is so herskryf dat Jahwe alle eer moes ontvang. Op hierdie manier het die heersersaansprake van die Assiriese koning en die Assiriese god, Assur, hulle totalitêre aansprake verloor. In hierdie verset het Israel sy eie identiteit ontdek en is die andersheid van sy God besef. En in hierdie daad van verset moet die begin van die Pentateug gesoek word (Otto 1998:60-84; 1999:1-90; 2000: 43-83).

\section{DIE JERUSALEMSE GESKIEDSWERK (JG): DIE BASISVERHAAL VAN DIE PENTATEUG}

'n Belangrike probeem waarmee die Pentateugkritiek worstel, is die voor-eksiliese omvang van die Pentateug. Wat het voor $586 \mathrm{vC}$ bestaan? Vroeër was die antwoord maklik: die werk van die Jahwis tydens die Dawid-Salomo-era het die vroegste grondslag gelê (Schmidt 1982:73-75; Gottwald 1985:137). Gedurende die afgelope dekades is die sekerhede in verband met die Jahwis en die vroeë koningstyd ondermyn. Die Jahwis is of baie later geplaas of het heeltemal van die toneel verdwyn (vgl Van Seters 1999:59-67). Dit het die probleem egter vererger want wat het dan voor die ballingskap bestaan? Een moontlikheid is die JG (Jerusalemse Geskiedswerk). Hierdie werk word tydens die bewind van Manasse geplaas. Of in elk geval tussen die val van Samaria in $722 \mathrm{vC}$ en die begin van die Manasse-era in 697 vC. Die eerste basisverhaal van die Pentateug het dus eeue na Dawid-Salomo ontstaan en dit wou ook onder geen omstandighede die bestaande koninskap legitimeer nie. Dit het gedurende die Assiriese bewind ontstaan en wou eerder die bestaande regering kritiseer asook die Assiriërs ondermyn (Zenger 1998:167-176). 
Aanvanklik het die JG uit die volgende bestaan: die AbrahamSara- en die Abraham-Lot-vertelsiklus (Gen 12:10-19:1ff*); die Jakobsiklus wat eers in die noordryk ontstaan het en toe in die suide uitgebrei is (Gen 25:19-36:40*); die Josefsgeskiedenis wat aanvanklik ook in die noordryk begin is (Gen 37:1-50:*); die uittogverhaal (Eks 1:1-14:31*) en dele uit die Sinaiverhaal (Eks 19:1-34:*). Daarbenewens is 'n groot aantal verhale en wetsversamelings wat oral in omloop was, in die JG opgeneem. Vanweë die verskeidenheid materiaal wat die skrywer(s) van die JG gebruik het, vertoon die werk 'n wonderlike teologiese spanning. Veral word dit in die fynere nuanses oor die aard van God se betrokkenheid by mense gesien.

- In die aartsvadertyd is El aanbid. Kenmerkend van El is die koppeling aan die familie. Anders gestel: nie aan ' $n$ politieke groep of ' $n$ koning nie, maar aan die familie het El Hom verbind. En El se familiebetrokkenheid vertoon sekere belangrike trekke: die El-God laat Hom in die gewone dingetjies van elke dag ken; Hy verbind Hom aan die node en die behoeftes van gewone mense; Hy fokus op dit wat vir hulle belangrik is; Hy help dié wat swak is en is by diegene wat moedeloos is; Hy is sommer net daar en dit nogal sonder enige voorwaardes. El is ook nie 'n krygsgod nie: Hy help nie deur mag of geweld nie (Albertz 1992:61-62). Daar is ook nie die ongeduld met die ander gode nie (Albertz 1992:59).

- In die verhaal van Josef kry ons weer 'n ander beeld: Jahwe tree op 'n verhulde wyse in hierdie wêreld op. Hy is wel direk by Josef en sy mense se dade betrokke. Hy werk deur hulle doen en late en bereik sy doel deur hulle grootdoenerigheid, haat, nyd, jaloesie en leuens. Jahwe werk dus agter die skerms en byna onopsigtelik. Dat hy egter alles onder beheer het, is seker.

- Dan volg die era van die Egiptiese gevangenskap. Omdat die konteks radikaal verander het, is anders oor God begin praat. Dis nie meer die tyd van die familie- en die El-godsdiens nie, maar van die groot groep en politieke bevryding. Op een of ander manier het 'n etnies verwante groep as krygsgevangenes in Egipte beland. Daar is hulle verdruk en hulle politieke regte ondermyn. Interessant is die manier hoe hulle nou oor God dink. Nou staan die groot groep met sy dwingende politieke behoeftes op die voorgrond en groot klem word op politieke bevryding geplaas. Jahwe kry gedurende die Egiptiese gevangenskap 'n "politieke" gestalte. Hy is die Een wat in hulle politieke nood ingryp en nuwe lewensmoontlikhede open (Albertz 1992:73-80). 
In die JG word vir die eerste keer 'n diepsinnige teologie van die geskiedenis aangetref. Uit al die oorgelewerde materiaal is ' $n$ koherente verhaal van Israel se vroeë geskiedenis saamgestel: "JG hat wohl erstmals die bis dahin getrennt überlieferten Erzählkreise über die Anfänge Israels so zu einem übergreifenden geschichtstheologischen Entwurf zusammengebunden" (Zenger 1998:175). Vroeër is die Troonbestygingsgeskiedenis van Dawid as die eerste werklike diepsinnige geskiedsteologie beskou. Met verloop van tyd het die aard van hierdie belangrike werk egter duideliker geblyk: dit beskryf bloot die opeenvolging van gebeure sonder enige besinning oor die aard van Israel se geskiedenis. So 'n teologiese refkleksie vind ons die eerste keer by JG (Zenger 1998:.171-172).

Te midde van die val van Samaria, die Assiriese bedreiging en die optrede van Manasse, word 'n samehangende "geskiedenisfilosofie" verskaf. Jahwe se hand word nie net in enkele losstaande gebeurtenisse nie, maar in die hele vroeë geskiedenis van Israel gesien. Hierdie vroeë geskiedenis was die plek en die manier waarop Jahwe Hom bekend gemaak het. Kortom: in hulle nadenke oor die vroeë geskiedenis (aartsvaders, uittog, woestyn, Sinai) het Israel 'n manier gevind om hulle verset teen die Assiriërs en hulle identiteit as geloofsgemeenskap te verwoord (Zenger 1998:175-176; vgl Seebass 1996:192; Schmid 1999:18-26).

\section{DIE PENTATEUG AS "GEESTELIKE LITERATUUR"}

Vir die Pentateugverstaan is die latere historiese gang van die Tora ook belangrik. So byvoorbeeld is die beweging van "versetsliteratuur" tot "geestelike literatuur" 'n betekenisryke gebeurtenis. Op 'n bepaalde stadium gedurende die vroeë Hellenistiese era het Israel se geloof 'n baie groter persoonlike karakter aangeneem. Elke Israeliet moes vir sy eie geestelike welsyn verantwoordelikheid neem. Meer nog: geestelike groei was aan ' $n$ boek (die Tora of die gekanoniseerde Pentateug) gekoppel. Hierdie "boekgodsdiens" het 'n totaal nuwe dimensie aan die geloofslewe verleen.

Die gelowige kon die woorde van die Tora vertrou: "want ek vertrou op u woord" (Ps 119:43); "ek stel my vertroue in u gebooie" (Ps 119:66); "By U skuil ek, U beskerm my, in u woord stel ek my vertroue" (Ps 119:114). Wie dit gelees het, het blydskap ervaar: "Dit gaan goed met die mens ... wat in die woord van die Here sy vreugde vind, dit dag en nag oordink" (Ps 1:1-2). Wie op die woord vertrou het, kon op die toekoms hoop: "Ek sien verlangend uit na die vervulling van u belofte" (Ps 119:82). Dit het riglyne vir die alledaagse lewe verskaf: "U woord is die lamp wat my die weg wys, die lig op my pad" (Ps 119:105). Oor en oor word van die liefde vir die woord vertel: "Hoe lief het ek u wet! Dit 
bly my elke oomblik by" (Ps 119:97); "U woord is baie suiwer, ek het dit lief" (Ps 119:140). Wie die woord uitleef, is 'n gelukkige mens: "Om volgens $u$ verordeninge te lewe, gee my meer vreugde as al die rykdom van die hele wêreld" (Ps 119:14). Die Tora het rigting aan die lewe gegee: "... ek (het) gedwaal, maar nou hou ek my aan u woord" (Ps 119:67).

Die persoonlike verhouding met Jahwe moes deur die lees van die Pentateug/Tora verinnig word. Anders gestel: die Pentateug/Tora was die "medium" waardeur die ontmoeting tussen God en die gelowige moes plaasvind. Deur die Tora/Pentateug het God baie naby aan elke gelowige gekom. In die omgang met die woord kon hulle Hom ervaar.

\section{SLOT}

Vandag se Pentateugkritiek dra die merke van die ingrypende veranderinge op die gebied van die wetenskapsteorie: daar is nie net een manier van verstaan nie, elke kyk op 'n teks belig maar net 'n klein fragmentjie van die tekswêreld, geen teorie kan ooit op ewige durende geldigheid aanspraak maak nie, elke teorie is sosio-histories bepaald, universele waarhede bestaan nie meer nie en daarom is elke lees slegs 'n greep en niks meer nie.

So ' $n$ benadering het geweldige gevolge vir die verstaan van Pentateug: die positiwistiese angel is uit die historiese kritiek geneem en ons kan met die eindelose moontlikhede wat die Pentateugkritiek ons bied, op 'n kreatiewe manier speel. Ten spyte van baie kritiek het die Pentateugondesoek van die afgelope twee eeue enorm baie bereik. Tot vandag toe bly dit baie kragtige verklaringsteorieë en niemand kan die Pentateug daarsonder bestudeer nie.

\section{Literatuurverwysings}

Albertz, R 1992. Religionsgeschichte Israels in alttestamentlicher Zeit, 1 \& 2. Göttingen: Vandenhoeck \& Ruprecht.

Blum, E 1984. Die Komposition der Vätergeschichte. Neukirchen-Vluyn: Neukirchener Verlag.

Cahill, J 1998. Archaeological evidence proves it. BAR 24/4, 34-41.

Collingwood, R G 1994. The idea of history. Oxford: University Press.

Davis, P R 1994. "House of David" built on sand. BAR 20/4, 28-40.

-, 1995. In search of "Ancient Israel". Sheffield: Academic Press.

De Knijff, H W 1980. Sleutel en slot. Kampen: Kok.

Frei, P \& Koch, K 1984. Reichsidee und Reichsorganisation im Perserreich. Göttingen: Vandenhoeck \& Ruprecht.

Frei, P 1984. Zentralgewalt und Lokalautonomie im Achämenidenreich, in: Frei \& Koch, 7-43.

Gabler, J P 1992. An oration on the proper distinction between Biblical and dogmatic theology and the specific objectives of each, Ollenburger, Martens \& Hasel, 489-502.

Gadamer, H-G 1990. Wahrheit und Methode. Tübingen: JCB Mohr. 
Gottwald, N K 1985. The Hebrew Bible. A socio-literary introduction. Philadelphia: Fortress Press.

Graf Reventlow, H \& Farmer, W (Hrsg) 1995. Biblical studies and the shifting of paradigms. Sheffield: Academic Press.

-, 1995. The role of the Old Testament in the German liberal Protestant theology of the nineteenth century, in: Graf Reventlow \& Farmer (Hrsg), 132-148.

Hayes, J H \& Prussner, F C 1985. Old Testament theology. London: SCM.

Houtman, C. 1994. Der Pentateuch. Kampen: Kok Pharos.

Kaiser, O 1984. Einleitung in das Alte Testament. Gerd Mohn; Gütersloher Verlagshaus.

Koch, K 1984. Weltordnung und Reichsidee im alten Iran, in: Frei \& Koch, 47-119.

Kratz, R G 1997. Redaktionsgeschichte/Redaktionskritik. TRE XXVIII, 367-378.

Kraus, H-J 1969. Geschichte der historisch-kritischen Erforschung des Alten Testaments. Neukirchen: Neukirchener Verlag.

Kuhn T S 1970. Structure of scientific revolutions. Chicago: Unversity of Chicago Press.

Le Roux J H 1997. Our historical heritage. OTE 10/3, 410-423.

-, 1998. Israel's past and the feeling of loss. (Or: Deconstructing the "minimum" of the "minimalists" even further). OTE 11/3, 477-486.

McBride, S D 1981. Deuteronomium. TRE VIII, 530-543.

Mehlhausen, J 1984. Geschichte/Geschichtsschreibung/Geschichtsphilosophie. TRE 12, 643-658.

Merk, O 1984. Gabler, Johann Philipp (1753-1826). TRE 12, 1-3.

Miller, M J \& Hayes, J H 1986. A history of ancient Israel en Judah. Philadelphia: Westminster Press.

Na'am, N 1998. Ancient texts prove it. BAR 24/4, 42-44.

Noth, M 1972. A history of Pentateuchal traditions. Englewood Cliffs, N J: Prentice Hall.

Otto, E (Hrsg) 2000. Mose. Stuttgart: Verlag Katholisches Bibelwerk GmbH.

-, 1994. Theologische Ethik des Alten Testaments. Stuttgart: Verlag W Kohlhammer.

-, 1995. Kritik der Pentateuchkomposition. ThR 60, 163-191.

-, 1996. Neuere Einleitungen in den Pentateuchkritik. ThR 61.332-341.

-, 1998. Die Ursprünge der Bundestheologie im Alten Testament und im Alten Orient. ZAR 4, 1-84.

-, 1999. Das Deuteronomium. Berlin: Walter de Gruyter.

-, 2000. Mose und das Gesetz. Die Mose-figur als Gegenentwurf Politischer Theologie zur neuassyrischen Königsideologie im 7. Jh. v. Chr, in Otto (red), 43-83.

Pannenberg, W H 1970. Basic questions in theology 1. London: SCM.

-, 1973. Wissenchaftstheorie und Theologie. Frankfurt: Suhrkamp.

Preuss, H D 1985. Heiligkeitsgesetz. TRE XIV, 713-718.

-, 1992. Theologie des Alten Testaments, 2. Stuttgart: Kohlhammer.

Prinsloo, W S \& Vosloo, W 1988. In mensetaal oor God se Woord. Pretoria: NG Kerk.

Rendtorff, R 1983. Das Alte Testament. Neukirchen-Vluyn: Neukirchener Verlag.

Rogerson, J 1984. Old Testament criticism in the nineteenth century. London: SPCK.

Saeb, M 1987. Johann Philipp Gablers Bedeutung für die biblische Theologie. $Z A W$ $99,1-16$. 
Sandys-Wunsch, J \& Eldredge, L 1980. J P Gabler and the distinction between Biblical and Dogmatic Theology: Translation, commentary and discussion of his originality. Scottish Journal of Theology 33, 133-158.

Schmid, K 1999. Erzväter und Exodus. Neukirchen-Vluyn: Neukirchener Verlag. Schmidt, L 1991. Literarkritik I, TRE XXI, 211-222.

Schmidt, W H 1982. Einführung in das Alte Testament. Berlin: Walter de Gruyter.

-, 1983. The faith of the Old Testament. Oxford: Basil Blackwell.

Seebass, H 1982. Elohist. TRE IX, 520-524.

-, 1987. Jahwist. TRE XVI, 441-451.

-, 1996. Pentateuch. TRE XXVI, 185-209.

Stolz, F 1995. Einführung in den Biblischen Monotheismus. Darmstadt: WBG.

Van Huyssteen, W 1986. Teologie as kritiese geloofsverantwoording. Pretoria: RGN.

Van Seters, J 1999. The Pentateuch. A social-science commentary. Sheffield: Sheffield Academic Press.

Von Rad, G 1958. Theologie des Alten Testament. München: Chr Kaiser Verlag.

-, 1971. Das formgeschichtliche Problem des Hexateuch, in Gesammelte Studien zum Alten Testament. München: Chr Kaiser Verlag.

Vosloo, W 1978. Die Abrahamsbeloftes in die Abrahamsvertellinge in Genesis. Pretoria: Universiteit van Pretoria.

Vosloo, W 1988. Die tuinverhaal. 'n Narratologiese ondersoek van Genesis 2-3, in Prinsloo \& Vosloo, 158-174.

Wellhausen, J 1963. Die Komposition des Hexateuchs und der historischen Bücher des Alten Testaments. Berlin: Walter de Gruyter.

Zenger, E (red) 1998. Einleitung in das Alte Testament. Stuttgart: W. Kohlhammer.

-, 1983. Gottes Bogen in den Wolken. Stuttgart: Verlag Katholisches Bibelwerk.

-, 1997. Priesterschrift. TRE XXVII, 435-446. 